УДК 811.163.41’367.5:811.163.2’367.5

https://doi.org/10.18485/msc50.2021.2.ch55

Ценка Иванова

\title{
СИНТАГМАТСКА ОРГАНИЗАЦИЈА ЛЕКСЕМА (КОЛОКАЦИЈА) КАО ДИСТИНКТИВНО ОБЕЛЕЖЈЕ КОД БЛИСКОСРОДНИХ ЈЕЗИКА - БУГАРСКОГ И СРПСКОГ
}

\begin{abstract}
У раду се паралелно и диференцијално описују постојеће комбинације творбених модела и лексичких спојева који функционишу у одређеним границама употребе у два генетски блиска и суседна језика, српском и бугарском.
\end{abstract}

Кључне речи: блискосродни (словенски) језици, спојивост језичке грађе, синтагматска организација лексема, творба речи, колокација, комбинаторика, језичка слика света, компарација, блиска различитост.

1. Један од аспеката поређења блискосродних језика јесте проналажење модуса кроз које би се показала специфична страна „блиске различитости” - заправо, исти инвентар домаћег или страног порекла који се не подудара у комбинаторици или, тачније, у спојивости на различитим нивоима језичке грађе. Та особина се нарочито испољава код творбе речи и у синтагматској организацији лексема. Велики је изазов описати паралелно и диференцијално постојеће комбинације творбених модела или лексичких спојева који функционишу у одређеним границама употребе у два генетски блиска и суседна језика, као што је случај са бугарским и српским. У принципу, поређења различитог типа између бугарског и српског су веома значајна за микротипологију компаративних истраживања, пошто та два језика показују занимљиву дистрибуцију одређених диференцијалних црта и специфичне резултате дијахронијских процеса у поређењу са словенским језицима источне и западне групе. Оријентација према различитим моделима језичке стандардизације од 19. века до наших дана доприноси још специфичнијем изразу оних дивергентних процеса који се могу укључити у две формуле: у творбени модел типа „исти инвентар - различита комбинаторика - значење”, у синтагматски 
модел типа „исти инвентар - разлика у комбинаторици - облик посебног језика".

Чињеница је да се савладавање и употреба два и више јужнословенских језика са методолошког и са психолингвистичког гледишта суочава са низом конкретних проблема због јако компликоване мреже диференцијалних карактеристика са слабим међусобним контрастима на основним структуралним нивоима с једне стране, а с друге - и због лавиринта лексичко-семантичких казуса не само на нивоу релација лексема (на првом месту то су међујезичка хомонимија и полисемија) него и код поређења синтагми које су конструисане са идентичним инвентаром. Ризично је преценити своје комуникацијске могућности када је реч о генетски блиском језику само на основу знања свог (матерњег) језика, ослањајући се на идентичности форме. Међујезичка изједначавања представљају компликован психолингвистички процес који је везан за проблематику форме и садржаја (Плотников 1989: 227). Упркос ставу да добро знање и коришћење више језика претпоставља разграничење подсистема и њихових компоненти на синрхонијском плану, у пракси се обично физичке јединице звука и јединице семантичког карактера поклапају у свести говорног лица у корист искуства из његовог првог језика ${ }^{1}$.

2. Синтагматском фактору као једном од главних чинилаца који одређује семантичку и синтаксичку структуру текста у последње време

1 У принципу се анализа свих језичких нивоа осим фонолошког везује за две полазне тачке: план израза и план садржаја - при чему се најчешће прихвата да први план одређује други. Према фонолошкој теорији Трубецког у говорној пракси се фонетске вредности препознају аутоматском селекцијом релевантних акустичких ефеката од нерелевантних применом познатих критеријума (аутоматски овде подразумева подсвесно, тј. критеријуме којима се остварује селекција битног од небитног и присутни су код човека још кад се језик учи). Пошто су критеријуми за селекцију усвојени према нормама познатог језика, у неочекиваном или изненадном контакту с новим језиком на који се човек још није привикао, идентификација фонетских вредности на страном језику није увек сигурна (Ивић: 144). Идентификација фонетских вредности или могућа одступања од норме или правилности у одређеном језику могу се показати како код посебних лексема, тако и код синтагми, тј. код неког лексичког скупа. Ова схватања касније су развијена са изузетно широком применом, нпр. како учити језике и коју методику примењивати у конкретном случају комбинације два и више језика. 
посвећује се све више пажње на плану синхронијских анализа унутар засебних језика².

2.1. Колокације - тј. начин на који лексеме функционишу заједно, одн. синтагматска организација лексема на предвидљив начин, веома се разликују од језика до језика и представљају једну од главних тешкоћа у савладавању страних језика (Кристал 2002: 90, 92, 105). Да би се створио одређени смисао о томе каква је која реч или које место она заузима, треба видети друштво у којем се она налази, при чему се у сваком језику лексеме организују синтагматски на „своје” начине са гледишта типологије. Одређена достигнућа компаративне лингвистике допринела су изграђивању теоријски заснованог става да се језици међусобно разликују не само по начину на који се гради реченица већ и по начину на који је свет подељен на елементе који служе као грађа за формирање реченица (Димитрова 1989: 72). Та страна лексичке спојивости веома је занимљива и са гледишта когнитивног приступа анализи феномена језика, и везана је за истраживања у области филозофије језика и дефинисања механизама стварања језичке слике света код различитих говорних представника ${ }^{3}$. У сваком природном језику одражава се одређени начин виђења или „концептуализације” света, заједнички за све говорнике тог језика. Говорни представник ствара језички израз и посредством „његовог” језика ванјезичка реалност постаје језичка. С друге стране, одређена концептуализација апстрактних садржаја не проистиче само из особености тих садржаја него и из национално-културне специфичности самог језика $^{4}$ што је још један разлог да се лексеме које их означавају спајају (или колоцирају) различито.

2 Такозвана конституентна граматика или наука о синтагми (буг. учение за словосъчетанието) релативно је нов правац у синтакси, мада га неки стручњаци сматрају сувишним (Бояджиев, Куцаров, Пенчев 1999: 506).

3 В. Хумболт утврђује да сваки језик поседује својеврсне и уникалне појмове или нијансе појмова - ово он објашњава чињеницом да се појам ствара посредством речи и у самој речи, а лексички састав датог језика никад не може бити у потпуности адекватан лексичком саставу другог језика (Димитрова 1989: 29). Према Ворфу, неопходно је проучити семантичку компоненту језика, садржај и значења која су фиксирана у њему. То значи да треба изучити не само речи или морфеме, него и оне везе међу речима и морфемама које су постале модели у датом језику. Управо од ових веза произлазе значења (Димитрова 1989: 54).

4 Појам језичка слика света уведен је у лингвистику релативно недавно, мада се о моделу света као специфичности етнокултурних традиција и о језичком одразу света који нас окружује као конкретна реализација тог модела говори увек када је у питању проблематика теорије и филозофије језика. Није овде у питању онај део специфичних карактеристика датог језика које се у на- 
2.2. Циљ овога рада јесте придружити се одговарајућом аргументацијом оним ставовима по којима треба још радити на компарацији колокације лексема и представити конкретне односе на том плану између бугарског и српског језика. Колокација сама по себи може се разматрати са теоретског и методолошког аспекта, може бити прагматички усмерена на дидактику и на лексикографски рад (Драгићевић 2004: 6162). Она поставља и бројна питања, а нека од најважнијих су: разликовање вишечлане лексеме од фразеологизма, устаљене конструкције итд. Стручњаци наглашавају да треба водити рачуна и о структурним, нормативистичким, контекстуално-ситуативним и узусно-стилистичким карактеристикама (Станишева 1988: 171). Семантички утицај једне лексеме на другу у линеарном низу такође је веома изазовно истраживачко подручје које захтева једну детаљнију вишеаспекатску анализу.

На компаративном плану може се издвојити посебан смер примењеног карактера, заправо, колокације код блиских (јужно)словенских језика у дидактици и у лексикографији ${ }^{5}$. У поређењу и у речницима треба обухватније укључити глаголску, субстантивну и адјективну рекцију, изнаћи могућности за лексикографско представљање осталих синтагматичких веза као што је место и значење предлога у синтагми итд. (Станковић 1997: 84).

2.3. Присуство ове теме у компаративним испитивањима још увек је слабо познато, можда због тешкоћа различитог карактера - нарочито код блискосродних језика као што је случај са словенским језицима. Још увек је у једнојезичним речницима информација о синтагматским везама и о могућностима лексичког спајања веома слабо заступљена. Тек се у новије време дошло до пуне свести о месту синтагматских веза и о значају њиховог усвајања у процесу успостављања и развијања двоје-

уци убрајају у етносемиотику - тј. тај садржај посебног језика који је везан за народну или националну својеврсност језичких знакова. То су, на пример, кинеме, проксематички знакови, митолошки и религијски симболи, особености у начину одевања итд., рецимо кинеме за „да” и „не” код различитих народа, знаци за поздрав, покрети тела или начин на који је тело укључено у комуникацији, дистанца међу саговорницима, али исто и брзина говора, вишак речи и гестова, јачина гласа и сл. Али, оријентација према одређеном моделу стандардизације или вековни културни или политички утицај неког другог језика су исто чиниоци који утичу на то да се лексичка спојивост инвентара заједничког порекла испољава различито.

5 „Бављење синтагматским везама не припада само граматици, већ једнако и лексикографији, на својеврстан начин и специфичној, и једнојезичној и двојезичној” (Станковић 1997: 84). 
зичја (Станковић 1997: 84). Истини за вољу, упућени у практични део остварења пројекта тог типа свесни су да је то тежак посао који захтева пуно времена, добро познавање двају језика и велику концентрацију стручних знања.

Највише радова посвећених колокацији у славистици односе се на компарацију руског језика са неким другим словенским језиком, укључујући и руско-бугарске и руско-српске паралеле. Досадашња нама позната истраживања у области српско-бугарске колокацијске проблематике показују да нема много покушаја да се та тема обради детаљније. Иначе, у последње време и српски и бугарски језички стручњаци посвећују више пажње проблему синтагматске организације речи у сваком од двају језика понаособ 6 .

3. У теоријама о синтагматској организацији лексичких јединица присутна су различита гледишта о месту и улози значења лексеме при њеном ступању у одређену колокацију. Према неким схватањима значење речи се може разложити на компоненте, на семе, при чему су неке централне или језгро основног значења, а друге семе су периферне. У колокацију ступају посебне семе двеју лексема и нису оствариве све могуће комбинације - тако се једна лексема веже са другом лексемом, али се са неком трећом не колоцира:

срп. перем и умивам - буг. пера и мия, умивам:

срп. перем (руке, косу, зубе, веш, кола) - умивам (лице)

буг. пера (пране) - мия (лице, рғи,е, зъби, коса, колата)

3.1. Компаративна анализа самосталних семантичких система или њихових фрагмената у синхронији и у дијахронији захтева типолошки прилаз. Тзв. микротипологија може показати како се у језику са истим или са веома блиским формалним средствима изражава различит садржај (Толстой 1968: 339 и д.). Управо типологија таквог типа који се односи на лексику и семантику остаје до сада непопуњено поље на шаховској табли језичког описа. Овај круг проблема поставља низ конкретних питања: 1) који су механизми за одређивање смисаоних граница речи; 2) који су подстицаји са ванјезичке стране и који су механизми за историјско премештање смисаоних граница речи; 3) како се дијахронијски мења наклоност речи за одређени тип спајања са другим речима у синтагматске низове (Виноградов 1968: 111). Промене у значењу облика у историји остају у већој мери загонетка, пошто је свака реч прошла кроз

6 У библиографији на крају рада представљен је део релативно новијих и актуелних радова из те области. 
низ метаморфоза при чему део њих показује веома битна разилажења са првобитном везом између форме и садржаја (Маковский 1989: 5).

3.2. С друге стране, на плану компаративних анализа језика и посебно генетски блиских језика важно место заузима питање о правилима семантичке спојивости захваљујући којима се остварује колокација.

Компаративна анализа у конкретном случају обухвата следећа питања:

1) C којим лексемама би могла нека лексема остварити лексичко слагање.

срп. чувам дете и гледам дете $\neq$ буг. чувам детето и гледам deme/mo

= буг. гледам дете $/$ то и виждам дете $/$ mo

2) С којим лексемама није могуће остварити лексичко слагање у језику Б за разлику од језика А; другим речима - треба истаћи и оне варијанте за које није могућа лексичка спојивост.

срп. пијем супу $\neq$ буг. ${ }^{*}$ пия супа (буг. ям супа)

срп. пијем супу = буг. пия бульон

срп. сечем месо - буг. сека дърва, кабел и режа месо

(код сека у буг. увек се мисли на брадву и сл., код режа - на нож тј. као позадинска знања треба имати у виду и оруђе радње)

срп. режем диск = буг. копирам диск

3) Код генетски веома блиских језика битан је још један аспект компарације - ако је лексичко слагање с неким лексемама могуће у принципу, с којима је пожељно или чак обавезно и самим тим - фреквентно, а с којима је само могуће, али није фреквентно или је стилски маркирано.

срп. песма - буг. песен

срп. певам песму и читам песму - буг. пея песен, чета стихотворение ( ${ }^{\star}$ чета песен?!)

срп. имам 22 године = буг. аз съм на 22 години (али: имам 22 години стаж)

срп. говорим и причам - буг. говоря и казвам

4) У овом случају је јако битно имати у виду још једну специфичну чињеницу карактеристичну за сваки језик као универзалну појаву и као специфично развијен инвентар семантичких трансформација - метафоризацију. Правац и распон уланчавања метафоричних екстензија 
несумњиво су од одређеног теоријског интереса, а са практичне стране је од немале користи систематизација свих врста лексичких разлика које постоје међу језицима, па и међу дијалектима унутар једног истог језика.

срп. X је преминуо. - буг. X почина.

- буг. Иван премина във втори клас. (Иван је уписао друго одељење) иельа)

срп. маска за кола - буг. престилка на колата (= буквално ке-

4. Као што је већ речено, у дидактици и у пратећој лексикографији дводелна конструкција као целина један је од аспеката разматрања међујезичких односа код блиских језика. Колокација као уопштени термин за синтагматску комбинацију лексичких јединица реализује се и конкретизује кроз посебне врсте речи и синтаксичке структуре. У терминолошком речнику та врста организације лексике поседује неколико кључних термина:

- Лексичка спојивост - подразумева се да је однос не само синтактички већ и семантички, указује се на то да постоји одређена законитост у синтагматском повезивању лексема;

- Лексемска валентност - способност једне лексеме у линеарном низу да, по одговарајућим семантичким и морфо-синтактичким правилима, привлачи друге (Драгићевић 2004: 66).

- Особину степен компактности неког лексичког споја условљавају три чиниоца: заменљивост, постојаност, прозирност. На основу та три фактора изводи се подела лексичких спојева на колокације и идиоме. Идиоми могу бити фразне лексеме (једном за свагда, тамо-амо), дискурсне формуле (ср. Драго ми је. = буг. Приятно ми е. Нема на чему. = Няма защо/Няма нищо.) и изреке (Нема дима без ватре. Свако зло има своје добро.)

Са гледишта категоријалне припадности конституенти синтагми могу остваривати следеће комбинације:

4.1. Именичка спојивост или именички тип колокације:

У поређењу са другим типовима колокација који следе даље, овај тип је најслабије заступљен и унутар њега се могу издвојити подтипови у даљем раду са више конкретног материјала:

срп. отварағе седнице - буг. откриване на заседанието

срп. лансиране Сојуза - буг. истрелване на ракетата Союз в opбuma 
4.2. Атрибутска спојивост: придев + именица

Атрибутски низови су више од две деценије атрактиван предмет дискусија на основу усвојеног гледишта да су граматичке структуре својеврсни одрази концептуалних структура и да у језицима постоји „преферирани редослед” унутар те врсте синтагме (Ивић 2002: 28 даје модел тог типа спојивости са примером тепа ирвена кожна торба).

Прва група синтагми показује класично стање код блискосродних језика, кад су сви конституенти присутни са својим основним значењем, само што се за одређени појам ствара различита комбинација саставних елемената:

срп. поштанско сандуче - буг. пощенска кутия

срп. јавно мнене - буг. обществено мнение

срп. главна пошта - буг. иентрална поща

На колокацијском плану који нас занима, неопходно је ставити акценат и на синтагме типа

срп. здрав - повређен $=$ буг. здрав - ранен (за живо биће)

буг. метафорично здрав - повреден $=$ срп. здрав - покварен $($ за технички уређај, машину и сл.)

Метафоризација различите конотације одређује разлику код елемената у синтагмама које изражавају исти појам у два језика - мада су и елементи из суседног језика добро препознатљиви:

срп. шећерна вуна - буг. захарен памук

Принцип појмовне блискости јавља се као незаобилазни оперативни фактор (Ивић 2002: 28), али стварање хомонимијских низова од формално једнаких синтагми у блиским језицима тражи више пажње:

срп. висока школа - буг. висше училище; срп. виша школа = буг. полувисше училище (више не постоји)

срп. свеже време - буг. хладно време (срп. хладно време - буг. студено време)

\section{3. Глаголска спојивост: прелазни/непрелазни глагол - именица}

Познато је да је за учење страног језика од великог значаја спајање речи, а највеће проблеме изазива спајање глагола, тј. комбинације глагола са другим речима у реченици. Глагол је центар целе реченице који је организује, који је везан за субјект и за допуне, као и за прилошке одредбе. Проучавање комбинација глагола са другим речима је неопходно 
како за коректно формирање целе реченице, тако и за правилну употребу самих глагола. Зато су речници глагола и приручници који садрже разноврсне податке о глаголима и о њиховој употреби у реченици преко потребни за школске установе, образовне институције где се све ради са различитим текстовима и, наравно, за појединце (нпр., за преводиоце, кореспонденте, новинаре) - Киршова 1997: 433. Осим речника глаголске валентности за сваки од језика требало би радити и на пројектима компаративних валентних речника - нарочито код блискосродних језика ${ }^{7}$.

срп. држим говор - буг. произнасям реч

срп. држим испит - буг. провеждам изпит

срп. дојим дете - буг. кърмя дете (буг. доя крава/овия - срп. музем краву/овиу)

срп. возим кола - буг. карам кола

срп. возим робу - буг. карам стока

Посебну пажњу треба обратити на асиметријске спојеве са гледишта синтагматске организације лексема, нпр.:

срп. поручити - буг. да отправя послание

буг. да поръчам - срп. оставити поруку

срп. роним = буг. гмуркам се (буг. роня изаревииа)

срп. Одговара ми да се сретнемо. - буг. Удобно ми е да се срещнем.

4.4. На компаративном плану проучавање предлошких система словенских језика код једнаких јединица неће бити завршено док се не узме у обзир синтагматска мотивација њихових употреба.

Питање о денотативном или лексичком значењу предлога није још увек решено једнозначно и сматра се отвореним - јер предлог, будући синтаксичка јединица, припада површинској структури језика, али истовремено зависи у највећој мери од лексичког окружења. Тешко је описати предлоге систематски, јер сваки предлог у конкретном тексту није самосталан, али његова веза са лексичким окружењем није формал-

7 Код глагола, када се разматрају у оквиру синтагме, постоје три главна појма: спојивост, валентност и рекција. Спојивост јесте најшири појам који указује на могућност повезивања глагола са било којим речима и који се разматра на нивоима граматике, семантике и лексике. Валентност је ужи појам и одражава обавезне, релевантне везе глагола са речима одређених граматичких група, као и способност глагола да реализује синтаксичке односе са субјектом, допунама и прилошким одредбама. Глаголска рекиија је још ужи појам који разматра само допуне уз глагол (Киршова 1997: 434). 
ног карактера, већ претпоставља узајамну усклађеност између семантике лексичких јединица, семантике предлога и осталих граматичких компоненти текста. Правила за избор датог предлога и његова семантика у зависности је и од семантичких особина лексичких јединица датог текста. Познавање синтагматских услова за функционисање предлога није периферни, него првобитни задатак у анализи њихових значења и употреба. Питање је да ли се међујезички подударају употребе предлога истог порекла кад су у питању словенске језичке компарације. Одговор се може добити тек после комплексног проучавања свих чињеница које одређују конкретна правила њихове употребе у одређеном контексту. У овом случају треба пре свега одредити групу глагола који поседују једнаку семантичку валенцу типа

буг. отивам на училище - врғщам се от училище срп. идем у школу - долазим из школе

У компаративним бугарско-српским радовима у којима се тражи тумачење правилне употребе предлога на основу контекста показује се, у ствари, управо неопходност обраћања посебне пажње на колокацију у формули глагол - предлог - именица.

срп. идем (одлазим, излазим итд.) - долазим (враћам се)

буг. отивам (излизам) - идвам ${ }^{\underline{8}}$ (врбщам се)

срп. идем уград - долазим из града идем у школу - долазим из иколе буг. отивам в града - идвам от града отивам на училище идвам от училище

срп. идем на факултет - долазим са факултета

буг. отивам вәв факултета - идвам от факултета

срп. излазим из... - падам с/са...

буг. излизам от - падам от

срп. одвојити од... - издвојити из...

(Одвојили су дете од мајке. Професор је издвојио неколико ученика.) буг. отделям от... - отделям от...

(Отделиха детето от майката. Преподавателят отдели няколко ученици.)

буг. отивам до магазина (отивам набързо, за кратко време) отивам на кино - отивам до киното

(... да гледам филм - ... по работа набързо)

8 Овај глагол се употребљава врло често погрешно и чак супротно због енантиосемиотичке карактеристике коју поседује на међујезичком плану. 
буг. забравих ключовете - забравих за ключовете

срп. заборавио сам кључеве - заборавио сам на ктучеве

(в. Ивић 2002: 119-120)

Неке конструкције су само на први поглед конкурентне и могу се узајамно заменити - у ствари, временом је свака конструкција постала самостални израз са сопственом семантиком (Лашкова 2002: 55).

срп. кутија од конзерве - не! *

буг. консервена кутия, али и кутия от консерва

Као што показују горе наведени примери, ред речи није занемарљив проблем и за крај, можемо парафразирати проф. М. Ивић (Ивић 2002: 31): „Све наоко ситне, а и за општелингвистичке теоријске увиде, и за свакодневну праксу граматичких описа у ствари релевантне разлике међу језицима које се тичу непосредно реда речи требало би што акрибичније осветљавати. Те разлике некад могу бити тако суптилне да их, при учењу страног језика, и не бисмо били довољно свесни без изричитог упозорења меродавних."

\section{ЛИТЕРАТУРА}

Бояджиев, Куцаров, Пенчев 1999: Тодор Бояджиев, Иван Куцаров, Йордан Пенчев, Съвременен български език, София.

Гортан-Премк 1997: Даринка Гортан-Премк, Полисемија и организација лексичког система у српскоме језику, Институт за српски језик САНУ, књ. 14, Београд.

Димитрова 1989: Стефана Димитрова, Лингвистична относителност, София.

Добрев, Добрева 1993: Добрин Добрев - Елка Добрева, Справочник на семиотичните термини, София.

Драгићевић 2004: Рајна Драгићевић, О терминима за колокацију и њене сегменте, Научни састанак слависта у Вукове дане, Београд, 33/3, 61-70.

Ивић 2002: Милка Ивић, Ред речи, Београд.

Ивић 1994: Milka Ivić, Pravci u lingvistici, Beograd.

Киршова 1997: Маријана Киршова, Нека запажања поводом структуре рекцијског речника, Научни састанак слависта у Вукове дане, Београд, 26/2, 433-439.

Кристал 2002: D. Kristal, Kembrička enciklopedija jezika, Beograd, 2002. 
Лашкова 2000: Лили Лашкова, Конкуренција језичких средстава у српској и бугарској реченици, Научни састанак слависта у Вукове дане, Београд, 29/1, 51-57.

Маслов 1987: Ю. С. Маслов, Введение в языкознание, Москва.

Пенчева 1998: Майа Пенчева, Човекът в езика. Езикът в човека, София.

Петровић, Дудић 1989: Владислава Петровић - Коста Дудић, Речник глагола са граматичким и лексичким допунама, Београд - Нови Сад.

Плотников 1989: Бронислав А. Плотников, О форме и содержании в языке, Вышэйшая школа, Минск.

Ристић, Радић-Дугоњић 1999: Стана Ристић - Милана Радић-Дугоњић, Реч. Смисао. Сазнање (студија из лексичке семантике), Београд.

Станишева 1988: Дина Станишева, К сопоставительной характеристике славянских предлогов с учетом синтагматического фактора. - Славянска филология, т. 19/Езикознание, 171-179.

Станковић 1997: Богољуб Станковић, Међуоднос граматике и речника у области синтагматских веза, Научни састанак слависта у Вукове дане, 26/2, Београд, 83-90.

Ценка Иванова

СИНТАГМАТИЧЕСКАЯ ОРГАНИЗАЦИЯ ЛЕКСЕМ (КОЛЛОКАЦИЯ) КАК ДИСТИНКТИВНЫЙ ПРИЗНАК БЛИЗКОРОДСТВЕННЫХ ЯЗЫКОВ БОЛГАРСКОГО И СЕРБСКОГО

Резюме

Одним из аспектов сопоставления близкородственных является выбор модуса, с помощью которого выявилась бы специфическая сторона „близкой различности”, а именно - тот же инвентарь отечественного или иностранного происхождения, не совпадающий в комбинаторике. Эта особенность нагляднее всего выявляется в словообразовании и в синтагматической организации лексем. Коллокации отличаются в языках и они являются частью формированной языковой картины мира у говорящих на отдельных языках. Они представляют один из главных вызовов при компаративном описывании близких языков на синтагматическом, а также на семантическом уровне. Коллокации представляют одну из главных трудностей в процессе овладевания иностранными языками - в частности, когда речь идет о генетически близких языках, и когда большая часть языкового 
инвентаря совпадает. Данная работа базируется на известных теоретических положениях. Автор предлагает классификационное распределение примеров из болгарского и сербского языков и пытается предложить возможный компаративно-типологический подход к данной проблематике. Кроме компаративного аспекта анализ генетически близких славянских языков обладает на данном уровне также прикладной ориентацией. 